\title{
DISTRIBUTED GENERATION OF PHOTOVOLTAIC SOLAR ENERGY: IMPACTS OF ANEEL'S NEW REGULATION PROPOSAL ON INVESTMENT ATTRACTIVENESS
}

\author{
GERAÇÃO DISTRIBUIDA DE ENERGIA SOLAR \\ FOTOVOLTAICA: IMPACTOS DA PROPOSTA DE NOVA \\ REGULAMENTAÇÃO PELA ANEEL NA ATRATIVIDADE \\ DO INVESTIMENTO
}

\author{
Diego Silva Cardoso ${ }^{1}$ \\ Pedro Sartori Locatelli ${ }^{2}$ \\ Wanderley Ramalho ${ }^{1}$ \\ Nader Asgary ${ }^{3}$ \\ 1 Fundação Pedro Leopoldo, Pedro Leopoldo - MG / Brazil. \\ 2 CEFET/MG, Campus BH, Belo Horizonte - MG / Brazil. \\ 3 Bentley University, Whalthan - MA / USA
}

\begin{abstract}
Purpose - The production of photovoltaic solar energy has gained international prominence, being the subject of government policies aimed at its development. The purpose of this study is to analyze the profitability of a shared photovoltaic solar energy project, located in the national territory, resulting from changes in regulatory framework of the sector represented by different tariff levels.
\end{abstract}

Design/methodology/approach - It is a quantitative study based on corporate finance as its theoretical-conceptual substrate. Simulations were carried out using different energy price and tariff scenarios.

Findings - The results reveal that, under current conditions, distributed photovoltaic solar energy generation is financially very attractive to investors. In addition, it was found that significant changes in the tariff regime for this type of energy might prevent new investments in the segment.

Practical implications - The evidence suggests caution in changing the legal framework of a segment that is still incipient in the country, which generates clean and renewable energy, and with enormous growth potential.

Originality/value - The study presents, in a systematic way, the possible impacts of changes in the price and tariff scenarios on the attractiveness of investment in the distributed generation of photovoltaic solar energy generation. In this sense, it can be easily adapted to evaluate industrial plant projects of different sizes in regions with distinct levels of solar irradiation.

Keywords - Sustainability, Photovoltaic Energy, Distributed Power Generation, Valuation. 


\section{RESUMO}

Objetivo - A produção de energia solar fotovoltaica tem ganhado destaque internacional, sendo objeto de políticas governamentais voltadas ao seu desenvolvimento. O objetivo deste estudo é analisar a rentabilidade de um projeto de energia solar fotovoltaica compartilhada, localizado em território nacional, decorrente de mudanças no marco regulatório do setor representado por diferentes níveis tarifários.

Desenho/metodologia/abordagem - É um estudo quantitativo baseado nas finanças corporativas como substrato teórico-conceitual. Foram realizadas simulações utilizando diferentes cenários de preços e tarifas de energia do segmento.

Resultados - Os resultados revelam que, nas condições atuais, a geração distribuída de energia solar fotovoltaica é financeiramente muito atrativa para os investidores. Ademais, foi constatado que mudanças significativas no regime tarifário deste tipo de energia poderiam dificultar novos investimentos neste segmento.

Implicações práticas - As evidências sugerem cautela em mudanças do marco legal de um segmento ainda incipiente no país, que gera energia limpa e renovável, e com um enorme potencial de crescimento.

Originalidade/valor - O estudo apresenta, de forma sistemática, os possíveis impactos das alterações dos cenários de preços e tarifas na atratividade do investimento na geração distribuída de energia solar fotovoltaica. Nesse sentido, pode ser facilmente adaptado para avaliar projetos de plantas industriais de diferentes portes em regiões com distintos níveis de irradiação solar.

Palavras-Chave - Sustentabilidade, Energia Fotovoltaica, Geração de Energia Distribuída, Avaliação de Investimento.

\section{INTRODUCTION}

The Brazilian electrical system presents itself as a large hydrothermal system nationally interconnected (SIN), with total installed capacity of 174,687 MW (Agência Nacional de Energia Elétrica [ANEEL], 2020). Hydroelectric generation contributes with $62.56 \%$ of the national electric matrix, which assures, worldwide, size and unique characteristics. On the other hand, the world energy matrix is predominantly non-renewable considering that it uses resources that, besides being highly polluting, mainly due to greenhouse gas emissions, cannot be replaced by man or by nature.

Globally, the conventional energy system is facing problems of progressive depletion of fossil energy resources and poor energy efficiency (Ferreira, Patah \& Faria, 2020; Rosa, \& Gasparin, 2016). These problems have led to a new trend of generating energy locally at lower voltage levels, using alternative sources such as wind power, photovoltaic, biofuels, among others (Krstić-Furundžić, Scognamiglio, Devetakovic, Frontini \& Sudimac, 2020; Rebelatto, Lange, Reginatto, Daneli \& Brandli, 2019; Reis, 2011).

There is evidence that the Distributed Generation (GD) of photovoltaic solar energy contributes to making the energy matrix cleaner, has less impact on nature, reduces electricity losses, optimizes the distribution network and makes consumers aware of the more rational consumption of energy. In Brazil, the advantages of GD are even more evident, due to the higher solar incidence in relation to the world average, which allows greater efficiency of the system (Dantas and Pompermayer, 2018).

Regarding the Brazilian case, Normative Resolution No. 482/2012 of the ANEEL entered into force, reformulated by Normative Resolution no. 687/2015. This Resolution allows the consumer to produce his own electricity and provides the surplus for the local distribution network, both individually and in condominiums/cooperative - called distributed generation (GD).

The Electric Power Compensation System allows consumers to install small generators, such as photovoltaic panels and wind microturbines, in their consumer unit and permute energy 
with the local distributor in order to reduce the value of their electricity bill. The validity period of the credits (more energy that the consumer unit generated) is 60 months. These credits can also be used to shoot down invoices from the consumer units of the same holder located in another location, provided that in the service area of the same distributor. This type of use of credits is known as "remote self-consumption". A novelty of the Resolution concerns the possibility of installation of distributed generation in condominiums, and that energy generated can be distributed among the owners in percentages defined by the consumers themselves (ANEEL, 2015).

Due to the incentives, there was a considerable increase in distributed generation, which does not require the use of internal batteries and uses photovoltaic inverters, being connected to the public distribution network. However, the distributed photovoltaic generation is in the initial phase of development, comprising only about 170,000 consumers out of 84.4 million (less than $0.2 \%$ ). These figures diverge largely from the mark of 2 million photovoltaic solar systems distributed in countries such as Australia, China, USA and Japan (Brazilian Photovoltaic Solar Energy Association [ABSOLAR], 2019).

Despite Brazilian low level of photovoltaic energy generation, ANELL proposes to change the regulation of $G D$, on the grounds that the system transfers costs to other energy consumers in the country (Ventura, 2019; Batista, 2019). The institution proposes that consumers of this type of energy pay a tariff that can range from $28 \%$ to $63 \%$. It is recorded that this type of policy was adopted in Spain in 2010 and made the generation of solar energy in that country unattractive for eight years. The policy was recently changed by adopting a system of electricity compensation equivalent to that currently used in Brazil. According to ABSOLAR (2019), the new regulation to investors and consumers has been paving the expansion of the sector enabling substantial investments and the generation of qualified jobs in that country. In California - USA, a world reference in the regulation of the sector, it was established a payment close to $10 \%$ (much lower than the claims of Brazilian energy distributors), only when GD reached the $5 \%$ mark in meeting the electricity demand of its distributors (ABSOLAR, 2019).

One cannot underestimate the relevance of the supply of renewable energy that should be part of a sustainable development strategy. The expansion is also important in generating jobs and the backward and forward linkage effects that affect other sectors of the economy. However, there is a gap characterized by the need for more systematic analyisis concerning the subject and based on solid theoretical/conceptual framework. This study addresses this theme and aims to present an appropriate analysis of the impacts produced by different tariffs levels on the investment attractiveness of distributed photovoltaic solar energy generation. In this sense, it sheds some light on the issue concerned to the country's photovoltaic solar energy progress. The theoretical-conceptual framework for achieving this objective, presented in section 2, provides the methodological tool consisting of discounted cash flow, risk and return on investment.

\section{THEORETICAL FRAMEWORK}

This section presents the legal framework and the main characteristics of distributed energy, as well as the conceptual aspects of value creation and the principles of valuation based on the discounted cash flow model. The steps for the analysis of the economic and financial viability of the implementation of a cooperative of distributed generation of photovoltaic energy requires the following information: risk of investment, the opportunity costs of invested capital and free cash flow forecast of a distributed photovoltaic generation unit over its useful life. 


\subsection{The generation of distributed photovoltaic energy}

Brazil has an energy matrix with a significant share of the so-called "clean energies", that is, those that do not come from fossil fuels, which are the main source of the world energy. The Brazilian energy matrix has the following configuration: hydric (62.56\%), wind (9.29\%); biomass (8.72\%); natural gas (9.1\%); petroleum products (5.26\%); mineral coal (2.05\%); nuclear (1.14\%); photovoltaic (1.88\%) (ANEEL, 2020). These figures reveal that a Brazilian energy matrix is based mainly on hydroelectric plants, but this system has operated very close to its limits.

Around the world, the conventional energy system is facing problems due to poor energy efficiency and the progressive depletion of fossil energy resources. These problems led to a new tendency to generate energy locally at lower voltage levels, using alternative energy sources. This type of power generation is called distributed generation (DG).

The generation of alternative energies has been experiencing a great expansion, but Brazil has not explored its high level of solar radiation $\left(1,500-2,500 \mathrm{~W} / \mathrm{m}^{2}\right)$ and large reserves of quartz that provide advantages for producing high quality silicon, cells and solar modules, which are materials of high added value (Nascimento, 2017). Thus, its generation of photovoltaic energy is still very small, only 3,287 MW (ANEEL, 2020).

In order to reverse this situation ANEEL introduced, in 2012, the Normative Resolution № 482/2012; establishing that the consumer can generate his own electric energy as DG from renewable sources or qualified cogeneration and, even, supply the surplus to the distribution network. Subsequently, the Resolution № 687/2015 presented the definitions of micro and mini generation. The first consists of a power generation plant with an installed capacity of $75 \mathrm{~kW}$ or less, for sources based on hydro, solar, wind, biomass and qualified cogeneration, connected to the distribution network through the facilities of consumer stations. The second, in turn, corresponds to the electricity generation plant with an installed capacity of more than $75 \mathrm{~kW}$ and equal to or less than five MW, using these sources.

Within the scope of this Resolution, the Electricity Compensation System was also created, allowing the consumers to install small generators, such as photovoltaic panels and wind micro turbines, in their consumer unit and exchange energy with the local distributor in order to reduce their electricity bill. The validity period of the credits (plus energy generated by the consumer unit) is 60 months, and these credits can be used to reduce the account of different units from the same holder.

A new feature of the standard concerns the possibility of installing distributed generation in condominiums, also known as shared generation. In this configuration, the energy generated can be distributed among the tenants in percentages defined by the consumers themselves. In both modalities - distributed generation and shared generation - compensation for energy credits generated at a location other than the energy consumption points of the beneficiaries of these credits (remote self-consumption) is allowed, provided that all the locations involved (production location and benefited consumers) are in the concession area of the electricity company (Diniz, Petrini, Barbosa, Christopoulos \& Santos, 2018).

The shared generation method came about with the aim of allowing members of a community to share the benefits of solar energy, even if they cannot or prefer not to install solar panels on their properties (Tongsopit, Moungchareon, Aksomkij \& Potisat, 2016). The Brazilian model of shared generation allows different arrangements, involving companies and individuals. Established the cooperative or consortium and duly authorized, amounts not fully offset in a single consumer unit can be used in other units, provided they are registered, have the same CPF or CNPJ and are located in the same area of the concessionaire. Furthermore, shared generation can refer to both community-owned projects and third-party power plants, whose electricity is shared among community members (Eassolar, 2018; Condomínio Solar Brasil [Cosol], 2016). 
Established that the photovoltaic solar energy GD is desirable, governments have implemented incentive policies aimed at its expansion. Among the successful cases, the experiences of Germany, the United Kingdom and the United States of America can be highlighted. In general, with small differences, these countries have adopted tax exemptions, special lines of credit with low interest rates and the Feed-in Tariff (FIT) with the obligation of electricity distribution companies to buy the energy generated via renewable sources (Dantas \& Pompermayer, 2018).

Germany has become a reference country in this segment, and the most active public policies to increase the installation of photovoltaic panels began in 1990. Over time, improvements have been made to the incentive system, with special attention to small systems that provided the population's engagement with the government's energy project. As a result, these systems connected in low voltage had an installed power in 2015 of $23 \mathrm{GW}$, representing $57 \%$ of the total photovoltaic capacity (Study Group of the Energy Sector UFRJ [GESEL], 2019). Although subsidies have been extremely successful in increasing the share of renewable sources in several countries, there are major controversies about their results from the perspective of productive efficiency, public finances and social justice. The debate is also taking place in Brazil and criticism of the system supports the new regulatory arrangement proposed by ANEEL for distributed generation - public consultation No. 25, 2019 (Silva, 2019).

Under the current Compensation System, as mentioned, the consumer injects into the distribution network the electricity generated and not consumed, obtaining energy credit to be used in up to 60 months, being remunerated by the average tariff paid to the concessionaire. According to critics (Secretariat for Evaluation, Planning and Energy [SECAD], 2019; Silva, 2019; Pompermayer, et al., 2018; Dantas \& Pompermayer, 2018), the model promotes an inadequate incentive system, mainly due to following factors: i) the consumers of the Compensation System served at low voltage are subject to the payment of a minimum amount that does not adequately remunerate the use of the distribution network, the corresponding difference being borne by the distribution companies and, mainly, by the other consumers of electrical energy outside this system; ii) energy is purchased by companies and other consumers at a price much higher than that which is being practiced in auctions organized by the Executive Power to serve the regulated electricity market; iii) GD is remunerated at the same amount as the distributor's tariff, without taking into account that the concessionaire's tariff is composed of the remuneration of the generation, transmission and distribution agents, in addition to charges and taxes; iv) the producer-consumer injects energy into the network at a time of low demand in view of supply, due to solar availability in the period from 8 am to $4 \mathrm{pm}$, and can use it at a time of high demand, and, thus, energy pricing supplied and consumed should take these specificities into account.

There is no doubt that recent technological advances in the area of semiconductors and the increase in solar cell production have helped to significantly reduce the price of photovoltaic systems (Diamandis, 2014). However, the commercialized price of energy by producer-consumers remains crucial to determine the capacity to generate value for mini and micro generation of photovoltaic power units, especially in lagging countries in the sector. In this way, government incentives may be needed to pave the way for expanding the use of this clean energy. To verify the feasibility of investments in micro and mini-generation of photovoltaic energy in the country, the discounted cash flow approach will be used, which even allows simulating possible scenarios of different energy prices and taxation on production and, thus, providing insights on ANEEL's proposals for changes in the regulatory framework. 


\subsection{Valuation - the discounted cash flow model}

There are three main approaches of valuation. Discounted cash flow assessment, which depicts the asset's value as the present value of an expected future cash flow; relative valuation in which the value of an asset is estimated with reference to the price of similar assets and the assessment of contingent rights, which uses real option pricing models (Damodaran, 2010).

The discounted cash flow model is recognized by the market for its greater technical and conceptual rigor, consequently, as most indicated in most evaluations (Póvoa, 2012). Furthermore, it allows simulating the main macroeconomic, operational and financial variables that are part of the evaluation methodology. The method also incorporates, in its calculations, the investor's preferences in relation to the risk-return conflict and the appropriate remuneration rate to equity (Félix, Locatelli, Fernandes \& Ramalho, 2016). Therefore, this method was adopted in the present study.

The principle that underpins financial decision-making is the ability of an asset to offer investors returns consistent with the risks involved. An investment decision adds value (wealth) to investors when the result obtained exceeds the cost of capital invested in the project (Bark \& Demarzo, 2017).

The DCF (discounted cash flow) model requires three variables for the estimates of the expected present value: the amount of cash flow, the temporal realization of this cash flow and the underlying risks. Mathematically, the model can be presented as follows:

$$
\text { Present value }=\sum \frac{\mathrm{FCL}_{\mathrm{t}}}{(1+\mathrm{r})^{\mathrm{t}}}
$$

Where, FCLt = free cash flow of the company in period $t$, covering revenues, expenses incurred and investments made; $r=$ discount rate represented by the opportunity cost of capital.

In economic theory, latter cannot be mathematically measured, while risk can be determined from the probability of investment results (Kishtainy, 2013). People generally understand risk as something negative that can generate an undesirable outcome in life. However, from the perspective of financial management, risk is not necessarily a synonymous for negative results. In the finance field risk is the probability of getting a return on investments other than those that have been designed and expected. Thus, the riskier the investment, the greater the demand of the investor for higher return (Damodaran, 2010). Eliminating the risk of an investment is not possible, but there is means of mitigating it.

There are two types of risks with distinct characteristics and nature: systematic and non-systematic risk. The diversification of the investment portfolio can mitigate the so-called non-systematic risk, since this is inherent to the operations of a company and comprises the risks on costs, scopes, deadlines and quality (Markowitz, 1952). However, the one that does not depend on the investor's effort, systematic risk, cannot be mitigated. It is a market characteristic, which is derived from political, economic, social and cultural conjunctures that influence the level of production, interest and inflation rates and affect investment outcomes.

\subsubsection{Risk, return and cost of capital}

All investment financing faces the risk and return ratio dilemma. The proper asset pricing can signal more efficient financing structure, which can vary among companies and segments. The raising of funds via equity and loans is the classic way to establish a capital structure for the sake of wealth generation (Felix, Locatelli, Fernandes \& Ramalho, 2016). 
Equity represents the investment of the partners in the company through both capital contributions and the retention of profits. Equity does not require a deadline for repayment. Consequently, this source of capital allows for greater financial flexibility to the company. In line with Modigliani and Miller's seminal contributions (Miller, 1988), the use of third-party capital can add value to investors arising from the tax incentives provided by the use of debt (Avelar, Cavalcanti, Pereira \& Boina, 2017).

However, as the project under analysis refers to a distributed energy cooperative that is exempt from income tax, its investors cannot earn the tax benefits that could generate savings and favor the use of third-party capital in the activity. In the present analysis the only source of capital to be used in the project comes from its own resources and, therefore, it was adopted an appropriate model for pricing this type of capital.

Following Copeland, Koller and Murrin (2012), estimating the opportunity cost of equity is quite challenging, as there is no simple market metric for this purpose. Thus, the measurement of the cost of equity is one of the most important steps of a company valuation process. The capital cost represents the remuneration provided to the suppliers of the resources. It shows the rate of return that a company must achieve in the projects so that there is no destruction of value to the investors (Maestri, Teruel, \& Ribeiro, 2016).

The Capital Asset Pricing Model (CAPM) was developed by Sharpe (1964), Lintner (1965) and Mossin (1966), based on the studies by Markowitz (1952) and Tobin (1958) on the selection of efficient portfolios in risk conditions. In this model, it is assumed no transactions costs, total liquidity in the markets in relation to the assets, symmetry between the information available in the market and the possibility of total diversification of the specific risk of the action, through the structuring of a portfolio. Thus, the model admits that the only risk assessed is expressed by the covariance between the asset and the market portfolio (non-diversifiable risk). All other risks are diversifiable and can be disregarded (Copeland et al., 2012).

The CAPM has been the subject of several criticisms (Fama \& French, 2004; Fama \& Stern, 2016; Fernandez, 2019), but it constitutes one the pillars of modern finance and remains as the most widely used approach for pricing the cost of equity (Levi \& Welch, 2016; Pratt \& Grabowski, 2014; Da, Guo, \& Jagannathan, 2012; Levi, 2012). Some hypotheses are necessary to apply CAPM model and they are, as seen, very restrictive, although they do not prevent the use of the model. Furthermore, according to Copeland et al. (2012) and Damodaran (2010), the cost-benefit ratio does not justify the adoption of an alternative and most complex model.

The CAPM presents the return of any asset as a function of the [systematic] risk assumed, as shown in equation 2 :

$$
E(R)_{i}=R_{f}+\beta \times\left(R_{m}-R_{f}\right)
$$

Where:

$E(R)_{i}=$ expected return (cost of capital) for an individual asset;

$\mathrm{R}_{\mathrm{f}}=$ risk free rate;

$\beta=$ measure of sensitivity that relates the return of the asset to the return of a market portfolio and portrays the systematic risk of the asset;

$\mathrm{R}_{\mathrm{m}}=$ expected return on the market portfolio.

\subsubsection{Beta as a systematic risk measure}

Beta is estimated utilizing a time series of a market-traded asset, which could limit its use to the list of publicly traded companies. However, there are ways to estimate a company's beta even 
if it does not trade assets in the market. According to Damodaran (2010), in the absence of market data regarding to the asset to be priced, one can adopt the bottom up method, based on companies with similar risks that are being traded in the market, either domestic or international.

The beta bottom up method has as a principle the logic that companies within the same sector tend to have differentiated betas due to financial leverage. Thus, the following steps should be undertaken: a) estimate the levered betas of similar companies; $b$ ) deleverage these betas considering their capital structure and estimate the average unlevered beta representative of the sector; $c$ ) leverage the obtained beta considering the specific capital structure (debt/equity) to be employed.

Leverage/deleveraging can be carried out through the equation 3.

$$
\beta \mathrm{L}=\beta \mathrm{U} \times\{1+[(\mathrm{D} / \mathrm{E}) \times(1-\mathrm{t})]\}
$$

Where:

$\beta_{\mathrm{L}}=$ levered beta;

$\beta_{U}=$ unlevered beta, risk situation without the presence of debt in the company's capital structure,

$\mathrm{D} / \mathrm{E}=$ debt/equity in market values;

$\mathrm{t}=$ income tax rate that will provide the tax benefit of the debt service.

\section{METHODOLOGY}

The object of the study is the impact analysis on the attractiveness of investment in a distributed energy generation industrial plant resulting from different tariff levels in the segment. The study can be characterized as descriptive, using a quantitative approach (Gil, 2008). The cash flow approach was used, allowing for the risk of invested capital. The major methodological procedures were simulations taking into account different energy price scenarios and alternative tariff systems. The data were processed using the software Eviews 9.0.

\subsection{The context of the research}

In 2016, Brazil had $81 \mathrm{MWp}$ of solar photovoltaic energy installed, a figure that corresponded to only $0.05 \%$ of total installed capacity in the country. The use of solar energy in the country is very low, given the average solar irradiation measured throughout the national territory $(1,500-$ $2,500 \mathrm{~W} / \mathrm{m}^{2}$ ), much higher than that of Germany, France and Spain, countries that invest a lot in this type of energy capture. In addition, the country has large quartz reserves, and can produce high quality silicon, solar cells and modules, which are high added value materials (Nascimento, 2017).

According to ANEEL's classification, the micro generation of distributed power consists of an electric power generation plant with an installed capacity of $75 \mathrm{~kW}$ or less, while the mini distributed power generation corresponds to the electricity generation plant with installed capacity of more than $75 \mathrm{~kW}$ and equal to or less than $5 \mathrm{MW}$. These plants can use energy-based sources from hydroelectric plants, photovoltaic, wind, biomass and qualified cogeneration (ANEEL, 2015). Photovoltaic power generation systems connected to the grid are the most common and widely used by homes and businesses. They do not need internal batteries and use common photovoltaic inverters, being connected to the public distribution network.

In cases where the power generation exceeds the demand, the residual power will be exported to the electricity grid, causing the user to receive a feed-in-tariff tariff (FiT) or credits to be slaughtered within 60 months for the energy available. The shared generation system came about 
with the goal of allowing members of a community to share the benefits of solar power, even if they cannot or prefer not to install solar panels on their properties. Project participants benefit from the electricity generated by the community solar farm, which costs less than the price they would normally pay their concessionaire. The shared generation can refer to both community-owned projects and third-party-owned power plants (COSOL, 2016).

According to the provisions of Law No. 5,764/71, a cooperative company contributes in a mutual way, using goods or services for common economic purposes, without the objective of making profits. The cooperative is a form of an autonomous, voluntary association that economically seeks to satisfy social and cultural needs from a collective and democratic business. It assumes a solidarity economy to obtain an efficient economic performance, based on the production of goods and services with quality directed to its cooperative members and customers. Cooperatives for the generation of electricity are considered unique and must have a minimum group of 20 members, and may be composed of individuals, exceptionally allowed the admission of legal entities that have as their object activities equal to or related to those of individuals (ANEEL, 2015; Eassolar, 2018).

Law No. 11,795/08 defines the consortium as a group of people or companies with a limited number of participants and with a certain period of operation aimed at contemplating goods or services from a self-financing system. The formation of a consortium focused on the generation of shared electricity is no different. It will depend on a company that will carry out the management of its process, seeking interested parties who enable the business, so that it can then manage and operate it. With regard to income, the company responsible for the administration may charge a fee for this service of the partners or associates. As long as provided in the contract, other amounts can be accounted for. Participation in the division of credits of power generation should be proportional to the investment made by each of the partners (BRASIL, 2017).

Each member will deposit his share in a collective fund, being managed with the purpose of keeping the project running. All the funds acquired by the consortium administration belong to the collective fund and are not part of its assets. Partners may be removed from the group in default situation, being reimbursed according to the amount of the investment applied.

\subsection{The unit of analysis}

The study refers to a cooperative of distributed generation of solar energy to be deployed in the municipality of Divinópolis in the Midwest region of the state of Minas Gerais, Brazil. The cooperative will be constituted in accordance with the legal framework and composed of twenty (20) consumers represented by small commercial companies and individuals, and the average monthly consumption of electricity of the members was estimated $12,110 \mathrm{kWh} / \mathrm{month}$.

To determine the generation capacity, the following formula was used:

$$
\text { Generation }=\text { Incident Radiation } \mathrm{x} \text { Efficiency } \mathrm{x} \text { Solar panel area }
$$

The following information was considered to estimate the size of the system, according to equation 4: Total Irradiation - Htot (Wh/ $\mathrm{m}^{2} /$ day) - calculated on Radiasol with data from the Solar and Wind Energy Resource Assessment (SWERA) and the system's performance rate in the municipality of Divinópolis in the order of 75\%. The results obtained are shown in Table 1. 
Table 1- Features of the shared photovoltaic power generation system

\begin{tabular}{ll} 
Characteristics & \multicolumn{1}{c}{ Size of the micro plant } \\
\hline System Size & $105 \mathrm{kWp}$ \\
Average monthly power generation & 11000 a $13000 \mathrm{kWh} / \mathrm{month}$ \\
Area required for system deployment & $750 \mathrm{~m}^{2}$
\end{tabular}

Source: Research data (2019).

The system to be implemented was estimated at $105 \mathrm{kWp}$ based on this information (Table 1). The estimated consumption is equivalent to approximately $96 \%$ of the generation capacity of this GD system. To accommodate the photovoltaic panels and other equipment necessary for energy generation, an urban area of $957.56 \mathrm{~m}^{2}$ was selected, on a flat land without vegetation and walled, located in the referred municipality. Of this area, $750 \mathrm{~m}^{2}$ will be allocated to the implementation of the system.

\subsection{Methodological procedures}

Revenue, administrative and operating costs, and capital expenditure were identified, as well as the cost of capital in order to proceed with the valuation and simulate the capacity of value creation by the Cooperative,

\subsubsection{Free cash flow}

The following elements had to be taken into account in order to build the free cash flow:

1) Total project revenue (quantity produced $x$ price in kWh of energy generated by the plant) over 25 years;

2) Deductions corresponding to the tariffs levied on revenues;

3) Operating and administrative expenses;

4) Company's operating result (total revenue - deductions - operating and administrative expenses);

5) Ebitda by subtracting the depreciation from the operating result;

6) Net capital expenditure (Capex - depreciation).

It is noteworthy that the activity is exempt from Income Tax and Social Contribution on Profit, which limits the use of third party capital that cannot benefit from tax deductions for the use of debt. A capital structure composed only of equity $(E)$, in such a way that the entire free cash flow of the project is destined to the cooperative members, was considered in the simulation.

\subsubsection{Operating revenue according to different price and tariff scenarios}

The operating revenue of the solar cooperative begins after the implementation of all systems, assuming that it will require a period of 03 months. Solar panels have a useful life of about 25 years and enable the efficiency of the system working with $80 \%$ of its installed capacity.

These parameters were adopted and the operating revenue was estimated considering the volume of kWh generated by the solar system and energy price scenarios. In 2019, the price of energy for consumers in-group $B$, which includes the members of the Cooperative, stood at $R \$ 0.89$ cent per kWh. This tariff was adopted, considering that the system works with equal compensation, that is, each kWh generated by the cooperative system kills one kWh consumed by members. Considering this price and the amount of produced energy, the Cooperative may generate revenues of the order of $R \$ 129,334.80$ annually, in values of 2019. 
Considering that the project will have a useful life of 25 years, it was necessary to project the effects on total revenue arising from the correction of electricity prices and the introduction of tariffs on energy supply. Regarding the adjustments in the price of energy, it was observed that in the last 11 years the energy tariff has presented an annual average correction of $6.26 \%$, a figure very close to the inflation rate that occurred in the country. These readjustments were, however, insufficient and the electricity sector faced serious financial difficulties.

Considering this scenario and bearing in mind that energy is a scarce asset, essential to society and a fundamental factor for economic growth, three scenarios of price were established:

Scenario A - annual increase in energy price corresponding to the projected inflation for the Brazilian economy, admitted at 3.5\% per year over the next 25 years;

Scenario B - annual increase in energy price higher than inflation by 0.56 percentage point, representing a real increase accumulated of $15 \%$ in the 25 years;

Scenario $C$ - annual increase in energy price higher than inflation by 1.05 percentage point, representing a real increase accumulated of $30 \%$ in the 25 years.

As for the change in the regulatory framework, ANEEL intends to introduce tariffs in distributed generation, and since January 24, 2019, Public Hearing 001/19 is open to discuss new energy compensation models for those who inject electricity into the grid from own systems using solar panels, as detailed in Table 2 .

Table 2 - Proposals for the introduction of tariffs in the distributed generation of energy by ANEEL

\begin{tabular}{|c|c|c|}
\hline Alternative & Equivalent Rates & Recipes \\
\hline $\begin{array}{l}\text { Alternative } 0 \text { - maintenance of the current } \\
\text { situation }\end{array}$ & $\begin{array}{l}0 \% \text { of the kilowatt-hour value } \\
\text { used }\end{array}$ & $\begin{array}{l}100 \% \text { of the energy injected } \\
\text { into the grid }\end{array}$ \\
\hline $\begin{array}{l}\text { Alternative } 1 \text { - payment to the equivalent of } \\
\text { transportation in the power distribution }\end{array}$ & $\begin{array}{l}28 \% \text { of the kilowatt-hour value } \\
\text { used }\end{array}$ & $\begin{array}{l}72 \% \text { of the energy injected in } \\
\text { the grid }\end{array}$ \\
\hline $\begin{array}{l}\text { Alternative } 2 \text { - payment to transportation in the } \\
\text { production and distribution of energy }\end{array}$ & $\begin{array}{l}34 \% \text { of the kilowatt-hour value } \\
\text { used }\end{array}$ & $\begin{array}{l}66 \% \text { of the energy injected in } \\
\text { the grid }\end{array}$ \\
\hline $\begin{array}{l}\text { Alternative } 3 \text { - payment to shipping and other } \\
\text { charges }\end{array}$ & $\begin{array}{l}\text { Alternative } 3 \text { - payment to } \\
\text { shipping and other charges }\end{array}$ & $\begin{array}{l}59 \% \text { of the energy injected in } \\
\text { the grid }\end{array}$ \\
\hline $\begin{array}{l}\text { Alternative } 5 \text { - payment for all tariff componen } \\
\text { except for the portion corresponding to the } \\
\text { purchase of energy }\end{array}$ & $\begin{array}{l}63 \% \text { of the kilowatt-hour value } \\
\text { used }\end{array}$ & $\begin{array}{l}37 \% \text { of the energy injected in } \\
\text { the grid }\end{array}$ \\
\hline
\end{tabular}

The outcome of this process is uncertain, with strong reactions from class associations, the legislature and even segments of the executive branch. The implications of each of the four taxation alternatives vis-à-vis the maintenance of the status quo will be analyzed in order to bring new elements to the debate on the possible effects of changes in the tariff regime. Naturally, gradual introduction of each of them will offer different results, but this does not invalidate the current exercise that will allow us to glimpse the possible effects of changing the regulatory framework on the profitability of projects. With the definition of the rules, new simulations can be made easily using the methods described here. 


\subsubsection{Operating expenses, depreciation and Capex}

The maintenance of the photovoltaic system is quite simple and involves only the preventive maintenance of the solar system, rent of the land, accounting advice, remote electronic security and the hiring of a manager. Operating and administrative expenses were budgeted at $R \$ 41,940.00$ annually and they were corrected according to the inflation expectation referred to in Scenario A. The decreasing value method was used, depreciating all investment in 10-year period. Cooperatives that comply with the provisions of the specific legislation are exempt from Social Contribution on Net Income and, therefore, in this case, there will be no taxation on the Cooperative's operating results.

For the implementation of the Solar Energy Cooperative, investments must be made in fixed capital (Capex) resulting from the acquisition of equipment related to the generation process, improvement works on the land to receive the equipment, installation of energy and water entry points. A total expenditure of $R \$ 276,100.00$ in 2019 values was estimated. The project will be implemented in three months, and the disbursement of this investment will be made over that period and the revenues will occur immediately after the completion of its implementation works for a period of 25 years. Working capital is not necessary for the cooperative of distributed generation of photovoltaic energy, since the operating expenses will be paid in an apportioned format among the members after the monthly compensation by the debit and credit system at the concessionaire.

\subsubsection{Capital cost}

The use of CAPM requires the knowledge of a risk-free rate, a financial market risk premium and a systematic risk of the asset, as shown by equation 2. The NTNB sovereign bond maturing on May 15, 2045 , with remuneration of $3.45 \%$ a year plus the variation of the IPCA was used as risk-free rate. Consequently, the risk-free rate $\left(R_{f}\right)$ was estimated at $6.95 \%$ per year, considering the fixed yield of the bond plus annual expected inflation of 3.5\%. A risk premium of $5 \%$ was admitted in line with estimates adopted in Silva, Locatelli and Lamounier (2016). The estimation of the beta is presented in the following section.

\section{ANALYSIS OF RESULTS}

The bottom-up method was used to determine the systematic risk of the business, with information from the share quotes of the company Centrais Elétricas de Minas S/A traded in $\mathrm{B}^{3}$ (Cmig3) and the index used as a proxy of the market portfolio (Ibovespa - IBV). This procedure is aligned with the discussions presented in section 2 , since Cemig is the concessionaire in the municipality of implementation of the analyzed project and, thus, is the company responsible for compensating the credits of the energy generated by the cooperative members. The leveraged beta obtained $\left(\beta_{L}\right.$ $=1.219$ ) and the relevant statistics are detailed in Table 3 .

Table 3 - CEMIG Beta Estimates

\begin{tabular}{lllcl}
\hline Variables & Coefficients & Standard Error & Statistics t & Prob. \\
\hline C & $-0,00013$ & 0,003637 & $-0,036545$ & 0,9709 \\
IBV & 1,21900 & 0,145208 & 8,39485 & 0,0000 \\
\hline
\end{tabular}

$\mathrm{R}^{2}=0,3153 \quad \mathrm{R}^{2}$ adjusted $=0,3108 \quad \mathrm{~F}=70,47$

Note: Weekly quotes of Cemig shares (Cmig3) and Ibovespa index (IBV) for the period 2017-2019, obtained from Yahoo Finance.

Source: Research data. 
This beta $\left(\beta_{\mathrm{L}}=1.219\right)$ was deleveraged using equation 3. Considering that Cemig's capital structure displayed in the period a D/E ratio of 0.5427 , the deleveraged beta $\left(\beta_{u}\right)$ was estimated at 0.79 and this coefficient was used to portray the project risk.

An estimated cost of capital opportunity inherent to the energy generation project of $10.90 \%$ per year was obtained. This was considered the prize to take on the risks inherent to the project, covering both market risks (energy price volatility), as well as other risks, including changes to the regulatory framework.

The estimate value of the project for the cooperative members was quantified taking into account the free cash flows over the life of the project and the opportunity cost of capital. According to the equation 1 , free cash flows were brought to present value by applying the discount rate corresponding to the opportunity cost of capital.

Table 4 summarizes the achieved results, presenting the estimated value at December 2019 prices and the estimated payback of the project. As discussed in the methodology, three scenarios were outlined in relation to the future trajectory of energy prices and simulated different levels of tariffs that would affect the revenues of distributed energy generation. Alternative 0 represents the status quo, assuming that the current rules are held for the next 25 years, while the other alternatives reflect different pricing possibilities, according to ANEEL's position.

Table 4 - Value generation of a photovoltaic energy cooperative at 2019 constant prices: simulations of the effects of different energy price scenarios and alternative tariff regimes

\begin{tabular}{|c|c|c|c|c|}
\hline $\begin{array}{l}\text { Tariff } \\
\text { Regimes }\end{array}$ & Methods & Scenario A & Scenario B & Scenario $\mathrm{C}$ \\
\hline 0 -zero rate & $\begin{array}{l}\text { present value } \\
\text { payback }\end{array}$ & $\begin{array}{l}\text { RS } 728.768,70 \\
3,9 \text { years }\end{array}$ & $\begin{array}{l}\text { RS } 811.567,35 \\
3,8 \text { years }\end{array}$ & $\begin{array}{l}\text { RS } 889.305,72 \\
3,7 \text { years }\end{array}$ \\
\hline $1-28 \%$ & $\begin{array}{l}\text { present value } \\
\text { payback }\end{array}$ & $\begin{array}{l}\mathrm{RS} 312.381,71 \\
7,1 \text { years }\end{array}$ & $\begin{array}{l}R S 371.996,74 \\
6,9 \text { years }\end{array}$ & $\begin{array}{l}R \bar{S} 427.968,36 \\
6,6 \text { years }\end{array}$ \\
\hline $2-34 \%$ & $\begin{array}{l}\text { present value } \\
\text { payback }\end{array}$ & $\begin{array}{l}\mathrm{RS} 223.155,92 \\
8,10 \text { years }\end{array}$ & $\begin{array}{l}\mathrm{RS} 277.803,04 \\
8,3 \text { years }\end{array}$ & $\begin{array}{l}\mathrm{RS} 329.110,02 \\
7,11 \text { years }\end{array}$ \\
\hline $3-41 \%$ & $\begin{array}{l}\text { present value } \\
\text { payback }\end{array}$ & $\begin{array}{l}\mathrm{R} S 119.059,18 \\
12,5 \text { years }\end{array}$ & $\begin{array}{l}\mathrm{RS} 167.910,38 \\
11,3 \text { years }\end{array}$ & $\begin{array}{l}R \bar{R} 213.776,02 \\
10,5 \text { years }\end{array}$ \\
\hline $4-49 \%$ & $\begin{array}{l}\text { present value } \\
\text { payback }\end{array}$ & $\begin{array}{l}\mathrm{RS} 91,46 \\
25 \text { years }\end{array}$ & $\begin{array}{l}\mathrm{RS} 42.318,78 \\
19 \text { years }\end{array}$ & $\begin{array}{l}\text { RS } 81.965,35 \\
16,4 \text { years }\end{array}$ \\
\hline $5-63 \%$ & $\begin{array}{l}\text { present value } \\
\text { payback }\end{array}$ & $-\mathrm{RS} 208.102,03$ & $-\mathrm{RS} 17 \overline{4}+46,53$ & $-\operatorname{RS} 148.703,33$ \\
\hline
\end{tabular}

Note: The discounted payback method was used and the result reveals the period of time required to recover the investments considering the cost of capital opportunity of the project.

Source: Research data.

The simulations presented show that the expected value generation of a distributed energy generation project is related to the different scenarios of increased energy prices and, above all, to the tax on the distributed generated energy.

The data in Table 4 reveal that in the specific case of a mini industrial plant of photovoltaic energy in the central west region of the State of Minas Gerais, the project is capable of generating excellent value for its investors under different price scenarios, maintaining the status quo of no inci- 
dence of tariffs on earned income. Alternative 0 -status quo - shows a generation of value close to $\mathrm{R} \$$ 800 thousands for investors. The time needed to recover the investment is very low, around four years.

At this point, it is interesting to contrast the results obtained, which replicates the current conditions without charging fees in earned revenues, with those of other studies conducted domestically. There is a consensus that, under the current regulatory framework, the generation of photovoltaic energy in the low voltage compensation system is very attractive and provides a very quick return on invested capital. Recent academic studies for different regions of the country reveal results similar to those presented in this article. For example, Persch A. (2020), in a quantitative study, concluded that the implementation of an energy system for the IFSC Campus São Carlos - SP would pay for itself in three years. Souza and Penha (2020) report a payback from the fourth year of operation of a DG plant in an industry in Rio Grande do Norte. Another study, aimed at analyzing the potential for reducing electricity costs for families with different income levels in the northern region of Mato Grosso, demonstrated that this objective would be economically viable from the fifth year onwards (Dalfovo, Zilio, Sornberger \& Redivo, 2019). Similarly, Freitas, Maria, Lannes and Souza (2018) present a valuation in which the implementation of a micro generation system for an HEI in Uberaba-MG foresees the total settlement of the investment in about five years. In addition, the aforementioned studies reveal that in addition to a relatively quick recovery of investment, there will be a high operational return on invested capital (ROIC), meaning that the project adds value to its investors.

However, the authors of this article have not identified academic studies aimed at assessing the impacts on the feasibility of investment in different energy price scenarios that would result from the change in the regulatory framework by ANEEL. Thus, in order to fill this gap, simulations were presented that contemplate possible trajectories of energy prices and the introduction of tariffs on energy generated by consumers-producers of small distributed generation plants. The results are shown in Table 4 and result from three energy price scenarios and five tariff regimes on distributed generation.

The simulations leave no doubt about possible perverse effects of a tariff policy on distributed energy generation activity. The adoption of a maximum tariff (alternative 5 ) with the payment of all components that currently fall in the country's energy companies, with the exception of the portion corresponding to the purchase of energy, would destroy the value of investors in GD systems, which is reflected in the negative net present value. In such a situation, the return on invested capital would be lower than the minimum rate required by investors that is corresponding to the opportunity cost of the capital used in the micro plant project.

If there were a tariff imposition of $41 \%$ - alternative 3 - the value generated by the project would reduce in figures close to $80 \%$, based on comparison the alternative 0 that portrays the current situation. As a result, the project estimated return could require a period that lasts more than ten years.

Even for a tariff close to $34 \%$ (alternative 2), it could result in unattractive profitability to potential investors in distributed photovoltaic projects. Considering that in the present simulations the spread on the risk-free rate was only $3.5 \%$ a year, it seems reckless to carry out a project whose return would require about eight years for the recovery of investment. The period is relatively long, given the uncertainties of a turbulent country in which the rules of the game change constantly lacking a healthy business environment.

Finally, it is necessary to examine the set of results obtained in this study from a general perspective. In this sense, it is legitimate to argue that it was a matter of presenting a set of methodological procedures with the potential to become a very useful instrument for the actors immediately involved and who need greater clarity on the economic, social, environmental and institutional consequences resulting from projects concerning the generation of shared photovoltaic energy.

Contrasting the results obtained with the theoretical framework, it was found that the GD system of low voltage photovoltaic energy, under the aegis of the current regulatory framework, generates a great return to the producer-investors involved, in addition to the positive environmen- 
tal aspects. This system with the set of tax and price incentive measures allows a high return on invested capital, which explains the success of the program and the great dynamism in the implantation of photovoltaic energy plants in the country.

However, it is evidenced by the reviewed literature that the system promotes imperfections in the market, increasing the cost of energy made available by the concessionaires. As consumer-producers do not pay the fixed costs involved in the transmission and distribution of energy, adherence to the system raises tariffs for those who do not have distributed generation. Therefore, this system provides incorrect economic incentives for decision-making by consumers who no longer pay for the use of the network, but still need the service provided both to generate and to consume electricity (SECAD, 2018; Silva, 2019). Therefore, "... an increase in the margin encourages more consumers to turn to self-generation, setting up an unstable feedback mechanism - a type of Ponzi scheme - that ultimately must fail to the detriment to those with and without solar panels" Hartley (2017 ). Thus, the current model harms consumers who do not participate in the system, including those from the lower income classes, who do not have access to resources to participate in this potential source of extra income, aggravating distributional problems.

\section{FINAL REMARKS}

This study aimed to simulate the possible effects on the development of the distributed generation of photovoltaic energy segment resulting from changes in the regulatory framework. It was examined the introduction of tariffs on distributed generation, as proposed by Aneel under discussion by the National Congress. The analysis was carried out based on a distributed micro generation cooperative project to be implemented in the southeastern region of the country. Its dimension and technical specifications were based on a survey on the profile of the electricity consumption of the members and the specific conditions of total irradiation. The amount of investment required implementing the micro-plant, the expected revenue and expense flows over the project's useful life and the estimated economic and financial risk of the project were detailed.

From the perspective of financial sustainability, any investment is subject to the expected return on the capital invested, which must be compatible with the risk assumed. CAPM was used as a model to price the opportunity cost of capital, and it was therefore necessary to estimate the systematic risk (beta). Since the enterprise to be built does not have assets traded on the market, the bottom up method was adopted. The systematic risk (unlevered beta of the project) was calculated at 0.79 and, consequently, the equity opportunity cost of capital was estimated at $10.9 \%$ yearly, assuming a free risk of $6.95 \%$ and a $5 \%$ financial market risk premium.

Proper tools were used to analyze the value generation according to different scenarios involving relative energy price outlook and the introduction of tariffs on energy consumption in a distributed generation system. It was shown that, under the current conditions, the distributed generation of photovoltaic energy is financially very attractive, generating a high value for investors who recover their investment in a few years of the project's operation. However, this scenario can undergo profound changes due to the tariffs to be imposed by the regulatory agency, which can make investment much less attractive and even unfeasible.

The evidence presented in the article points out the need for caution in changing a system that has been showing dynamism, generates clean and renewable energy and promotes regional growth, in a period of GDP stagnation and high levels of unemployment. It should be noted that although the volume of capital required to implement a micro-plant is relatively low, projects of this nature are fully justified and together they can cause favorable impacts on the economy. They create value for their investors, contribute to the generation of clean energy and preservation of 
the environment, and stimulate the production of equipment and machines that can be produced internally. Thus, such a project should receive encouragement from government agencies, considering that the levels of solar radiation are abundant despite being of very little used of the country. The widespread micro and small photovoltaic power plants could constitute a new investment opportunity, contributing to improve the Brazilian energy matrix and foster regional economies. This is particularly important in a period of GDP stagnation and high levels of unemployment. It must be emphasized that the procedures utilized in this study can be applied to different contexts besides allowing new simulations as ANEEL clearly defines its tariff proposal. Particularly, such simulations can be developed for several project sizes in different Brazilian regions with distint radiation levels. The model can also be extended to take into account the effects of a capital structure that includes both own and third party capital on project financing.

To conclude, although greater participation of solar energy in the Brazilian energy matrix and the population in the provision of this service is desirable, it must be recognized that the expansion of the system in the current institutional arrangement could generate some market imperfections, with adverse distributional consequences. Thus, broader studies aimed at analyzing costs and benefits in the environmental, efficiency and equity dimensions are recommended, aiming to improve tariff regulation and guide the necessary stimuli for the sustainable growth of the sector.

\section{REFERENCES}

Agência Nacional de Energia Elétrica. (2012). Resolução Normativa no 482/2012. Retrived on June 12, 2019, from http://www2.aneel.gov.br/cedoc/ren2012482.pdf

Agência Nacional de Energia Elétrica. (2015). Resolução Normativa № 687. Retrived on June, 12, 2019, from http://www2.aneel.gov.br/cedoc/ren2015687.pdf

Agência Nacional de Energia Elétrica. (2020). Sistema de informações de geração ANEEL Siga. Retrived on January 18, 2020, from https://bit.lyArcos-Vargas, A., Nuñez, F., \& Vivas, J. J. (2019). Efficiency improvements in the PV plants market: an application to the Spanish case, International Journal of Energy Sector Management, 13(1), 229-254.

Associação Brasileira de Energia Solar Fotovoltaica (2019). Mudança de regras da energia solar na geração distribuída vai na contramão do mundo. Retrieved on November 29, 2019, from http://www.absolar.org.br/deixeasolarcrescer/

Avelar, A., Cavalcanti, M., Pereira, R., \& Boina, T. (2017). Determinantes da estrutura de capital: um estudo sobre empresas mineiras de capital fechado. Revista Evidenciação Contábil \& Finanças, 5(2),23-39.

Baptista, R. (2019). Senadores criticam proposta da Aneel de taxar geração de energia solar. Retrieved on November 14, 2019, from

https://www12.senado.leg.br/noticias/materias/2019/10/31/senadores-criticam-proposta-daaneel-para-taxar-geracao-de-energia-solar

Berk, J., \& DeMarzo, P. (2017), Corporate Finance. (4th. ed.). New York: Pearson.

Brasil. (2017). Decreto № 9.022, dispõe sobre a conta de desenvolvimento energético, a reserva global de reversão e o operador nacional do sistema elétrico. Retrieved on March 25, 2019, 
from https://www2.camara.leg.br/legin/fed/decret/2017/decreto-9022-31-marco-2017784560-publicacaooriginal-152288-pe.html

Copeland, T., Koller, T., \& Murrin, J. (2012). Avaliação de empresas (valuation) - calculando e gerenciando o valor das empresas. São Paulo: Pearson.

Condomínio Solar Brasil. (2016). Condomínio solar: o que é? Retrived on March 20, 2019, de https:// www.cosol.com.br/blog/condominio-solar-energia-solar

Da, Z., Guo, R., \& Jagannathan, R. (2012). CAPM for estimating the cost of equity capital: interpreting the empirical evidence. Journal of Financial Economics 103(1), 204-220.

Dalfovo, W. C., Zilio, P. C., Sornberger, G. P., \& Redivo, A. (2019). A Viabilidade econômica da implantação de energia solar fotovoltaica para a redução dos custos com energia elétrica das famílias com diferentes níveis de renda: uma análise para a região norte de Mato Grosso. Sociedade, Contabilidade e Gestão,14(3),118-143.

Damodaran, A. (2010). Avaliação de investimentos: ferramentas e técnicas para a determinação do valor de qualquer ativo. Rio de Janeiro: Qualitymark.

Dantas, S. G., \& Pompermayer, F. M. (2018). Viabilidade econômica de sistemas fotovoltaicos no Brasil e possíveis efeitos no setor elétrico. IPEA - Texto para Discussão, n. 2388. Brasília - DF. Retrived on March 01, 2021, from https://www.ipea.gov.br/portal/images/stories/PDFs/TDs/ td_2388.pdf

Diamandis, P. (2014). Solar energy revolution: a massive opportunity. Forbes. Retrived on February 26, 2021, from https://www.forbes.com/sites/peterdiamandis/2014/09/02/solar-energyrevolution-a-massive-opportunity/?sh=2c27a726c900

Diniz, E. H., Petrini, M., Barbosa, A. F., Christopoulos, T. P.,\& Santos, H. M. (2018, abril). Levantamento da geração distribuida compartilhada no Brasil. Anais do VII congresso brasileiro de energia sola, Gramado - RS, Brasil. 12.

Eassolar. (2018). Geração de energia compartilhada. Retrived on March 06, 2019, from http:// eassolar.com.br: http://eassolar.com.br/geracao-compartilhada.php

Fama, E., \& French, K. R. (2004). The capital asset pricing model: theory and evidence Journal of Economic Perspective 18 (3), 25-46.

Fama, E., \& Stern, J. M. (2016). A look back at modern finance: accomplishments and limitations. Journal of Applied Corporate Finance 18(4), 10-16.

Felix, F. S., Locatelli, R. L., Fernandes, F., \& Ramalho. W. (2016). Construção civil no Brasil: criando ou destruindo valor? Revista de Gestão e Projetos, 7(1), 70-82.

Ferreira, H. L., Patah, L. A., \& Faria, R. M. (2020). Evidence of existence winner's curse between enterprises wind and photovoltaic power generators winners of the 8th reserve energy auction. Revista de Administração da UFSM - ReA, 13 (Special Edition), 1459-1475.

Fernandes, P. (2019). 18 topics badly explained by many finance professor. University of Navara IESE Business School. Retrived on June 11, 2019, from https://papers.ssrn.com/sol3/papers. cfm?abstract_id=3270268 
Freitas, R., Maria, W., Lannes, L. R., \& Spuza, W. (2018). Estudo de viabilidade da implantação de um sistema de micro geração de energia fotovoltaica para Facthus. XVI CELL. Universidade de Uberlândia - MG. Retrived on February 26, 2021, from https://www.peteletricaufu.com/ static/ceel/artigos/artigo_297.pdf

Gil, A. C. (2008). Métodos e técnicas de pesquisa social (6a ed). São Paulo: Atlas.

Grupo de Estudo do Setor Energético UFRJ (2018). Experiências internacionais em geração distribuída: motivações, impactos e ajustes. Rio de Janeiro - RJ. Retrived on February 12, 2021, from http:// gesel.ie.ufrj.br/app/webroot/files/IFES/BV/livro_experiencias_internacionais_em_gd.pdf>.

Hartley, P. R. (2017). DOE and net metering: issues to consider. Forbes. Sep, 2017. Retrived on March 1, 2021, from https://www.forbes.com/sites/thebakersinstitute/2017/09/26/doe-and-netmetering-issues-to-consider/?sh=71242abf647b

Kishtainy, N. (2012). The economics book. London: Dorling Kindersley Limited.

Krstić-Furundžić, A., Scognamiglio, A., Devetakovic, M., Frontini, F., \& Sudimac, B. (2020). Trends in the integration of photovoltaic facilities into the built environment, Open House International, 45 (1), 195-207.

Levi, H. (2012). The capital asset pricing model in the 21st century: analytical, empirical, and behavioral perspectives. New York: Cambridge University Press.

Levi, Y., \& Welch, I. (2016). Best practice for cost-of-capital estimates. Marshall School of Business Working Paper. Retrived on June 15, 2019, from https://papers.ssrn.com/sol3/papers. cfm?abstract_id $=2667735$

Lintner, J. (1965).The valuation of risk assets and the selection of risky investiments in stock portfolios and capital budgets. Review of Economics and Statistics, 47, 13-37.

Maestri, C. O., Teruel, R. L., \& Ribeiro, K. C. (2016). Governança corporativa e o impacto no custo de capital próprio. Revista de Finanças Aplicadas, 7(4),1-17.

Markowitz, H. (1952). Portfolio selection. The Journal of Finance, 77-91.

Miller, M. H. (1988). The Modigliani-Miller propositions after thirty years. Journal of Economic Perspectives, 2(4), 99-120.

Mossin, J. (1966). Equilibrium in a capital asset market. Econometrica, 34(4), 768-783.

Nascimento, R. L. (2017). Energia solar no Brasil: situação e perspectivas. Brasília: Câmara dos Deputados.

Persch, A. (2020). Análise da viabilidade de um sistema de energia solar fotovoltaica no Campus São Carlos do IFSC. Retrived on March 25, 2020, from https://repositorio.ifsc.edu.br/bitstream/ handle/123456789/1416/ARTIGO\%20ANDRIELI.pdf?sequence=1\&isAllowed=y

Póvoa, A. (2012). Valuation: Como Precificar Ações. Rio de Janeiro: Campus.

Pratt, S. P., \& Grabowski, R. J. (2014). Cost of capital (5th ed.). Hoboken, New Jersey: Wiley.

Rebelatto, B., Lange A., Reginatto, G., Daneli, R., \& Brandli, L. (2019). Energy efficiency actions at a Brazilian university and their contribution to sustainable development goal 7. International Journal of Sustainability in Higher Education, 20(5), 842-855.

Rev. Adm. UfSM, SANTA Maria, v. 14, N. 2, April-JUne, P. 423-442, 2021 
Reis, L. B. (2011). Geração de energia elétrica (2a ed.). Barueri: Manole.

Rosa, A. R., \& Gasparin, F. P. (2016). Panorama da energia solar fotovoltaica no Brasil. Revista Brasileira de Energia Solar. 7(2), 140 - 147.

Secretaria de Avaliação, Planejamento, Energia e Loteria. (2019). Visão da SECAP sobre o setor de energia; o caso da micro e minigeração distribuída. Brasília - DF. Retrived on February 02, 2019, from https://pt.scribd.com/document/446722910/Visao-Da-Secap-Sobre-o-Setor-deEnergia-o-Caso-Da-Micro-e-Minigeracao-Distribuida

Sharpe, W. F. (1964) Capital asset prices: a theory of market equilibrium under conditions of risk. The Journal of Finance, 19(3), 425-442.

Silva, R. M. (2019). O novo arranjo regulatório proposto pela Aneel para a geração distribuída na consulta pública № 25, de 2019. Núcleo de Estudos e Pesquisas da Consultoria Legislativa. Boletim Legislativo 82. Brasília - DF. Retrieved on December 02, 2019, from https://www12. senado.leg.br/publicacoes/estudos-legislativos/tipos-de-estudos/boletins-legislativos/bol82

Silva, T. V., Locatelli, R. L., \& Lamounier, W. M. (2016). Abertura de capital e retornos aos acionistas: o caso da Companhia de Saneamento de Minas Gerais S/A. Revista Gestão e Tecnologia, 16(1), 7-32.

Souza, G. R., \& Penha, R. S. (2020). Viabilidade econômica de um projeto de investimento de energia fotovoltaica. Revista de Auditoria, Governança e Contabilidade - RAGC, 8(35), 113-128.

Sindicato dos Engenheiros no Estado de São Paulo. (2019). Aneel quer taxar ainda mais a geração de energia solar. Retrived on October 20, 2019, from https://www.seesp.org.br/site/index.php/ comunicacao/noticias/item/18090-aneel-quer-taxar-ainda-mais-a-geracao-de-energia-solar

Tobin, J. (1958). Liquidity preference as behavior toward risk. Review of Economic Studies, 25(2), 65-86.

Tongsopit, S., Moungchareon, S., Aksomkij, A., \& Potisat, K. (2016). Business models and financing options for a rapid scale-up of rooftop solar power systems in Thailand. Energy Policy. 95, 447-457.

Ventura, M. (2019). Aneel quer reduzir incentivo para quem produz sua própria energia: proposta ainda pode sofrer alterações. Retrived on October 20, 2019, from https://oglobo.globo.com/ economia/aneel-quer-reduzir-incentivo-para-quem-produz-sua-propria-energia-24019355 


\section{AUTHORS}

\section{Diego Silva Cardoso}

Master in Business Administration at Fundação Pedro Leopoldo

Email: diegocardoso02@hotmail.com

ORCID: https://orcid.org/0000-0002-3462-8344

\section{Pedro Sartori Locatelli}

BA in Electrical Engeneering at Centro Federal de Educação Tecnológica de Minas Gerais - CEFET/MG

Email: pedrosartloc@gmail.com

ORCID: https://orcid.org/0000-0003-3318-0194

\section{Wanderley Ramalho}

Doctor in Business Administration at Universidade Federal de Minas Gerais

Email: w.ramalho@yahoo.com.br

ORCID: https://orcid.org/0000-0001-8720-3449

\section{Nader Asgary}

Ph.D in Economics at University of Houston

Email: nasgary@bentley.edu

ORCID: https://orcid.org/0000-0003-3358-7701

\section{CONTRIBUTION OF AUTHORS}

\begin{tabular}{|c|c|c|c|c|}
\hline Contribution & [Author 1] & [Author 2] & [Author 3] & [Author 4] \\
\hline 1. Definition of research problem & $\mathrm{V}$ & $\mathrm{V}$ & & \\
\hline $\begin{array}{l}\text { 2. Development of hypotheses or research questions } \\
\text { (empirical studies) }\end{array}$ & $\sqrt{ }$ & $\sqrt{ }$ & & \\
\hline $\begin{array}{l}\text { 3. Development of theoretical propositions } \\
\text { (theoretical work) }\end{array}$ & $\mathrm{V}$ & $\mathrm{V}$ & & \\
\hline 4. Theoretical foundation / Literature review & $\mathrm{V}$ & $\mathrm{V}$ & $\mathrm{V}$ & \\
\hline 5. Definition of methodological procedures & $\sqrt{ }$ & $\sqrt{ }$ & & \\
\hline 6. Data collection & $\mathrm{V}$ & & & \\
\hline 7. Statistical analysis & $\mathrm{V}$ & $\sqrt{ }$ & $\mathrm{V}$ & \\
\hline 8. Analysis and interpretation of data & $\mathrm{V}$ & $\mathrm{V}$ & $\mathrm{V}$ & \\
\hline 9. Critical revision of the manuscript & & & $\mathrm{V}$ & $\sqrt{ }$ \\
\hline 10. Manuscript writing & $\mathrm{V}$ & $\mathrm{V}$ & & \\
\hline 11. Other (please specify) & & & & \\
\hline
\end{tabular}

\section{Conflict of Interest}

The authors have stated that there is no conflict of interest.

\section{Copyrights}

ReA/UFSM owns the copyright to this content.

Plagiarism Check

The ReA/UFSM maintains the practice of submitting all documents approved for publication to the plagiarism check, using specific tools, e.g.: CopySpider. 